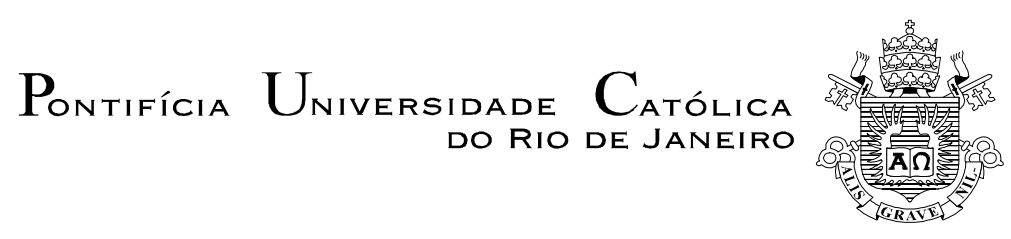

Ana Paula Grillo El-Jaick

O ceticismo nos estudos da linguagem: sobre Contra os gramáticos, de Sexto Empírico

Tese apresentada como requisito parcial para obtenção do grau de Doutor pelo Programa de Pós-Graduação em Letras do Departamento de Letras do Centro de Teologia e Ciências Humanas da PUC-Rio.

Orientadora: Prof ${ }^{a}$. Dr $\stackrel{\text { a }}{ }$. Helena Franco Martins

Rio de Janeiro

Julho de 2009 


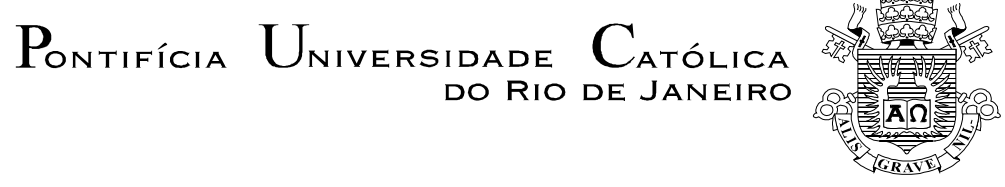

Ana Paula Grillo El-Jaick

\section{O ceticismo nos estudos da linguagem: sobre Contra os gramáticos, de Sexto Empírico}

Tese apresentada como requisito parcial para obtenção do grau de Doutor pelo Programa de PósGraduação em Letras do Departamento de Letras do Centro de Teologia e Ciências Humanas da PUC-Rio. Aprovada pela Comissão Examinadora abaixo assinada.

Profa. Helena Franco Martins
Orientadora
Departamento de Letras - PUC-Rio

Prof. Danilo Marcondes de Souza Filho

Departamento de Filosofia - PUC-Rio

Profa. Maria Paula Frota

Departamento de Letras - PUC-Rio

Prof. Luiz Henrique Lopes dos Santos USP

Prof. Vanise Gomes de Medeiros UERJ

Prof. Paulo Fernando Carneiro de Andrade Coordenador Setorial do Centro de Teologia e Ciências Humanas - PUC-Rio 
Todos os direitos reservados. É proibida a reprodução total ou parcial do trabalho sem autorização da universidade, da autora e da orientadora.

\section{Ana Paula Grillo El-Jaick}

Graduou-se em Direito na UFF (Universidade Federal Fluminense) em 1999 e em Letras em 2005 na mesma Universidade. Cursou Filosofia na UFRJ (Universidade Federal do Rio de Janeiro) entre 2000 e 2002. É doutoranda em Letras na PUC-Rio (Pontifícia Universidade Católica do Rio de Janeiro), desenvolvendo pesquisa na linha das Abordagens nãorepresentacionistas do significado: aporias e perspectivas, sob orientação da Prof. Helena Franco Martins.

Ficha Catalográfica

El-Jaick, Ana Paula Grillo

O ceticismo nos estudos da linguagem : sobre Contra os gramáticos, de Sexto Empírico / Ana Paula Grillo El-Jaick ; orientadora: Helena Franco Martins. - 2009.

197 f. ; $30 \mathrm{~cm}$

Tese (Doutorado em Letras)-Pontifícia Universidade Católica do Rio de Janeiro, Rio de Janeiro, 2009.

Inclui bibliografia

1. Letras - Teses. 2. Ceticismo. 3. Linguagem. 4. Contra os gramáticos. 5. Sexto Empírico. 6. Wittgenstein, Ludwig, 1889-1951. I. Martins, Helena Franco. II. Pontifícia Universidade Católica do Rio de Janeiro. Departamento de Letras. III. Título. 
Para Helena, porque sem ela este objeto exterior realmente não existiria. 


\section{Agradecimentos}

À minha orientadora.

À minha família.

Aos meus amigos.

Aos professores Danilo Marcondes de Souza Filho e Maria Paula Frota pela leitura atenta e pelas valiosas contribuições na Qualificação desta tese.

Aos demais professores da PUC-Rio, em especial aos Professores Paulo Henriques Britto e, novamente, à Professora Maria Paula Frota.

Ao Professor Francis Wolff, cuja orientação no período em que estive na École Normale Supérieure (Paris), com bolsa PDEE, foi fundamental para o desenvolvimento desta tese.

Aos funcionários da PUC-Rio.

Ao CNPq, à CAPES e à PUC-Rio pelos auxílios concedidos, sem os quais este trabalho não poderia ter sido realizado. 


\section{Resumo}

El-Jaick, Ana Paula Grillo; Martins, Helena Franco. O ceticismo nos estudos da linguagem: sobre Contra os gramáticos, de Sexto Empírico. Rio de Janeiro, 2009. 197p. Tese de Doutorado - Departamento de Letras, Pontifícia Universidade Católica do Rio de Janeiro.

Esta tese é uma análise de Contra os gramáticos, tratado sobre a linguagem escrito quase vinte séculos atrás pelo cético Sexto Empírico. Dedicando-se a esse importante capítulo na história das idéias lingüísticas, o estudo tem em seu horizonte mais amplo contribuir para o entendimento das relações entre ceticismo e linguagem. Responde, em especial, a um cenário contemporâneo em que as virtudes das palavras para o entendimento e a comunicação são recorrentemente postas em dúvida - nas artes em geral, e também em expressiva parcela das reflexões teóricas produzidas no âmbito das ciências humanas e sociais. Partindo da hipótese de que o exame de uma das mais remotas manifestações do pensamento cético sobre a linguagem pode nos ajudar a compreender esse cenário, a pesquisa teve como perguntas norteadoras as seguintes: (i) que perspectiva(s) de linguagem informa(m) os argumentos de Sexto Empírico em seu tratado Contra os gramáticos? e (ii) Sob que aspectos da linguagem a dúvida cética recai nesse tratado? $\mathrm{O}$ antigo texto foi assim interrogado por meio de uma abordagem conscientemente anacrônica: tomamos como balizas de análise perspectivas contemporâneas de linguagem, a saber, aquelas que inflamaram o debate filosófico no âmbito da assim chamada virada lingüística, em que se pode discernir a oposição básica entre uma visão pragmática e uma visão representacionalista da linguagem. Reconhecendo que a contenda adquire inflexões substantivamente distintas conforme os autores que se tenha em mente, optamos aqui por tomar como referência mais específica a manifestação do referido antagonismo na filosofia de L. Wittgenstein - levando em conta sobretudo os interlocutores que dialogam em suas Investigações filosóficas. Uma primeira conclusão do estudo é que convivem na trama argumentativa de Contra os gramáticos duas proto-imagens de linguagem, associáveis respectivamente ao representacionalismo e ao pragmatismo. Outra conclusão a que chegamos é que, em 
Contra os gramáticos, a dúvida cética incide sobre a idéia de uma ordem intrínseca à linguagem, mas não sobre as suas virtudes práticas, cotidianas. Mostraremos ainda que a noção de linguagem comum, central em Contra os gramáticos, tem ali um status de solução, contrapondo-se a ambições metalingüísticas vistas como nocivas e fadadas ao insucesso. Por fim, concluímos que uma análise da mesma noção de linguagem comum em outras obras de Sexto Empírico desestabiliza esse status: a linguagem comum passa então a receber cuidados e a despertar escrúpulos sugestivos de que pode ser ao mesmo tempo solução e problema.

\section{Palavras-chave}

Ceticismo - linguagem - Contra os gramáticos - Sexto Empírico - Wittgenstein 


\section{Abstract}

El-Jaick, Ana Paula Grillo; Martins, Helena Franco (Advisor). Skepticism in the field of language studies: on Sextus Empiricus' Against the Grammarians. Rio de Janeiro, 2009. 197p. PhD Thesis - Departamento de Letras, Pontifícia Universidade Católica do Rio de Janeiro.

This thesis is an analysis of Sextus Empiricus' Against the Grammarians - a skeptical treatise on language written almost twenty centuries ago. In addressing this important chapter in the history of linguistic ideas, the study aims more broadly at the understanding of the relationship between language and skepticism. It is thus specially responsive to a contemporary scenario, where the virtues of language to promote understanding and communication are systematically placed under suspicion - in the arts in general, as well as in a significant part of the theoretical reflections in human and social sciences. Assuming that the examination of one of the remotest manifestations of skeptical thought about language may help understanding this contemporary scenario, this research was guided by the following questions: (i) what perspective(s) on language inform(s) Sextus Empiricus's arguments in Against the Grammarians?; and (ii) what aspects of language fall under skeptical doubt in this treatise? The ancient text was thus interrogated by means of a deliberately anachronic strategy: our analysis took contemporary perspectives of language as points of reference - views that inflamed philosophical debate after the so-called linguistic turn, and can roughly be distributed between a pragmatic and a representationalist perspective. Since the dispute assumes quite different inflections according to the authors one has in mind, we have opted to focus on the manifestation of this debate within the philosophy of L. Wittgenstein, notably by taking as references the opposing voices that come into dialogue in his Philosophical Investigations. A first conclusion of this study is that two proto-images of language coexist within the argumentative web of Against he Grammarians, views that parallel the representationalist and the pragmatic contemporary stances. Another conclusion is that, in this ancient treatise, skeptical doubt falls over the idea that language has an intrinsic order, but not over language's practical and day-to-day virtues. 
It will be shown further that the notion of common language, central in Against he Grammarians, has there the status of a solution, in contrast to metalinguistic ambitions that are viewed as fated to failure. We show, finally, that an analysis of the same notion of common language as it appears in other works by Sextus Empiricus dislocates and disturbs this status of solution: for common language is there the object of concerns and scruples that suggest that it may be at the same time a solution and a problem.

\section{Keywords}

Skepticism - language - Against the Grammarians - Sextus Empiricus Wittgenstein 


\section{Sumário}

1. Introdução 13

2. Isto é um objeto de comparação 21

3. Ceticismo antigo 40

3.1 Sexto Empírico 45

4. Ceticismo antigo e linguagem 62

$\begin{array}{ll}4.1 \mathrm{O} \text { afásico fala } & 62\end{array}$

4.2 Sexto Empírico e a linguagem: panorama geral 65

4.2.1 Sexto Empírico e os signos estóicos 65

4.2.2 O falante como cronista; a linguagem como testemunho 77

4.2.3 As expressões céticas 83

4.3 A linguagem no ceticismo antigo com olhos contemporâneos 87

5. Contra os gramáticos 95

5.1 A gramática 95

$\begin{array}{ll}5.2 \text { Sobre a tradução de technê } & 104\end{array}$

$\begin{array}{ll}5.3 \text { Contra os professores dos estudos liberais } & 108\end{array}$

5.4 Contra que gramática? 113

5.5 A linguagem não se reduz: o uso é infinito - etc. 116

5.6 Contra a analogia e em defesa do uso comum 126

5.7 Contra os gramáticos e sua idéia de uma racionalidade $\begin{array}{ll}\text { intrínseca à linguagem } & 131\end{array}$

5.8 Contra a possibilidade de se fazer metalinguagem 136

5.9 Por uma metalinguagem mínima: ler / escrever 141

5.10 Hipotiposes de Contra os gramáticos 143

$\begin{array}{lr}\text { 6. Vida comum, linguagem comum } & 148\end{array}$

6.1 O uso comum: Sexto Empírico e Wittgenstein 
$\begin{array}{lc}\text { 7. Conclusão } & 184\end{array}$

8. Referências bibliográficas 191

$\begin{array}{ll}8.1 \text { Obras de autores antigos } & 191\end{array}$

8.1.1 Sextus Empiricus 191

8.1.2 Outros autores antigos 191

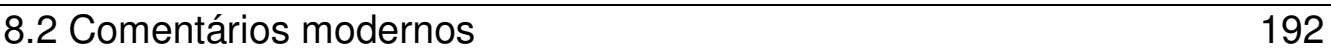

8.2.1 Sobre a questão da linguagem no ceticismo 192

8.2.2 Outros estudos sobre o ceticismo 193

8.2.3 Ludwig Wittgenstein 195

8.2.4 Sobre Wittgenstein 195

$\begin{array}{ll}8.3 \text { Outros trabalhos utilizados } & 196\end{array}$ 
"Raphèl maí amècche zabí almi"1 Dante Alighieri, A Divina Comédia

${ }^{1}$ Palavras incompreensíveis de Nemrod, construtor da torre de Babel (Inferno, XXXI, 67). 